Article

\title{
Present status and re description of Iranibarbus or Luciobarbus barbuls Heckel 1849 a valid Cyprinidae species of Iran
}

\author{
Jalal Valiallahi ${ }^{*}{ }^{*}$ Brian W. Coad ${ }^{2 *}$ \\ 1-Environmental Science Department, Shaheid Rajaee Teacher Training University, Lavizan, Tehran, Iran. \\ Postal Code: 1678815811 \\ 2 Research Scientist, Ichthyology Section, Canadian Museum of Nature, Ottawa, Canada \\ Email: briancoad@hotmail.com \\ *Corresponding author, Email: jvaliallahi@srttu.edu $\quad \underline{\text { Iraneesd@yahoo.com }}$
}

\begin{abstract}
Western Iran Barbus species, are scientifically, environmentally and economically important. Some of them are the largest riverine freshwater species, that will grow in size and weight to $170 \mathrm{~cm}$, and $120 \mathrm{~kg}$ respectively. These species although are vulnerable species but there is scarce information on taxonomy or present environmentally status of these exclusive species. Luciobarbus barbulus is one of the uniquely significant large species. In order to find new record on present status of large Barbus species a sampling program carried out in western Iran, during the resent year since 2013 to now. The validity of Luciobarbus barbulus a Cyprinid fish, which several authors have synonymies with different species is reaffirmed. This species overlaps in distinction with L. mystaceus, $L$ scheich, and other similar species. In this study re description of L.barbulus is given. Our study reviled that Luciobarbus barbulus(Heckel 1846) is valid species and differ from L. mystaceus, L scheich, L. kersin, L. pectoralis, L. rajanorum. L. barbulus is not a subspecies of Luciobarbus mystaceus (Heckel 1846). This species differs from L. mystaceus in having thick and very wide fleshy lip, inferior mouth and slightly shorter head. In Luciobarbus barbulus head is more inferior. The details of differences between these species are given. This species is one of stable growing fish without dimorphism, that retain it's shape from a fingerling species to a giant fish. The details on new record, new photo of this exquisite species and other precious large Luciobarbus species are given.
\end{abstract}

Keywords: Cyprinidae; Luciobarbus barbulus; Luciobarbus, Iran; taxonomy

\section{Introduction}

Identifying of fish species specifically according to original descriptor, is very important. It is substantially is a bases for future distinctive classifying of fishes by modern and precision tools, such as DNA fingerprinting or other molecular or biochemical studies. Without dependable knowledge on identifying different fish species, other kind of analyzing may led to more confusing, mixing and generating useless mass of data [1] Western Iran Barbus species, are scientifically, environmentally and economically important species. Some of them are the largest riverine freshwater species, that will grow in size and weight to $170 \mathrm{~cm}$, and $120 \mathrm{~kg}$ respectively. These species although are vulnerable, but there is inadequate information on taxonomy or present environmentally status of these exclusive species. Luciobarbus barbulus is one of these uniquely significant large species.

Luciobarbus barbulus was one of 15 species among specimens collected by Theodor Kotschy $1841-1842$, in the water system around Shiraz and was sent to Heckel in Vienna Museum (NMW).

Luciobarbus barbulus briefly described by Heckel (1849)[2]. But during the last decades it has been reported and described for several times. Despite Heckel(1849) described some of distinctive features of Luciobarbus barbulus and outlined its difference with Luciobarbus mystacus but from 1970 arise some doubts about validity of this species. However There are also conflicting views on the 
validity and synonymy of several nominal "Barbus" species.( See more details on www.briancoad.com) [3]

The possible syntype of Luciobarbus barbulus (NMW 53957) as stated by Almaça (1986)[4] and Coad (1997)[5] is in too poor condition. As some of morphological and meristic characters of Luciobarbus barbulus Heckel (1849), overlap with other similar species such as L. mystaceus, L scheich, L. kersin, L. pectoralis, L. longiceps, L. rajanorum. These species have been put a problematic group of Barbus species. The stated nominal species, more or less have a similar shape with Luciobarbus barbulus. So clear view on classifying of this species may be considered as a bases for morphological compression of other members of this group, description of this species may facilitate describing other related species.

In addition, recently arises more critical view on morphological classifying of fish species or on some less studied genus. "Like many other Cyprinids the Brbus genus was long included in Barbus. It appears to be a very close relative of the typical barbels - which include that genus type species Barbus barbus, and may well warrant inclusion in Barbus. Many modern authors prefer to consider it a subgenus instead. It is, moreover, not entirely clear what species to place in Luciobarbus if it is deemed valid. The IUCN argues for a rather inclusive circumscription. Non with standing the taxonomy and systematics of this ill-defined assemblage, their closest living relative is probably Aulopyge huegelii." [6].

\subsection{The exist problem on L. barbulus}

During the last decades L. barbulus has been reported and described for several times or has been synonymized with other related species.

According to Almaça, (1993), Günther (1868), based on Heckel's original description, Sauvage (1884) and Pellegrin (1923), based on specimens from the Orontes (Lake Homs, Hammah, and Antakya), Khalaf (1961) on specimens from Iraq, present descriptions of L. barbulus[10]. Berg (1949) based on Heckel's original description reported 4 specimens from Karun R. basin in Khuzistan Iran, [11] that apparently gathered by Zarudnyi in his travels throughout Iran in 1896, 1900-1901 and 1903-1904. [In original report the name of Arabistan is wrong, there is no place by name of Arabistan in Iran it is probably Khuzistan.][9]

Mahdi Nuri (1962) from Iraq reported Luciobarbus barbulus in Qezilja River (Leaser Zab)[12].

Saadati M.A. (1977) reported eight specimens from the tributaries of Saymareh and Tigris R.[13].

Valiallahi, (20000 in his PhD. Tesses on Barbus species of Iran states: "Despite the clear description of stated authors from 1970 arise some doubt about type locality and validity on $L$. barbulus. Also there was conflicting view on morphological character of this species" [14].

\subsection{Systematics}

Howes (1987) places this species in Barbus sensu stricto[15]. Almaça (1983)[16] placed L. barbulus as a subspecies of Luciobarbus mystaceus (Pallas, 1814) and synonym of Labeobarbus orontis Sauvage, (1882)( Krupp, F. 1985a)[17] .

Possibly syntype of L. barbulus (NMW 53957) was examined by Almaça (1986) He states that a probable syntype of L. barbulus (from Kara Agatsch, Iran) was found, but it is in so bad conditions that nothing can be recognised by its examination curiously, all the specimens which could be identified with L. barbulus original description proceed from the Mediterranean coast of Western Asia: Lake Tiberias (Israel), Orontes and Lake Homs (Syria), and Lake Antakya (Turkey). As L. barbulus was described from Iran there is here an intriguing geographical problem which can't be solved before more information be available. (Almaça 1983)[4,16]. Regarding similarity and overall morphology, Almaça realised that there is a close affinity between L. barbulus and group bocagei (Almaça 1984b, 1990). Later Almaça (1984a, 1984b, 1986, 1991) [4,9] retained barbulus as a full species known only from the Levant, despite Heckel's record from the Qarah Aqaj (= Mand) of Fars, Iran.(Coad, 2017) 
Krupp (1985) places Luciobarbus barbulus in Luciobarbus pectoralis Heckel, 1843 and gives data on the disposition of the holotype of Luciobarbus pectoralis (in the Naturhistorisches Museum Wien under NMW 54474, 116 mm standard length, 1839, Th. Kotschy [17, 18, 19]. Karaman (1971) places this species in the synonymy of Barbus rajanorum but other authorities consider it to be Luciobarbus pectoralis (q.v.)[20].

According to Karaman (1971) L. barbulus would be synonym of L. rajanorum or subspecies of $L$. rajanorum rajanorum[21].

Coad states that the synonymy of Luciobarbus barbulus with L. pectoralis remains uncertain(Coad, 2017)[3]. The possibly syntype of L. barbulus (NMW 53957) also was seen by Dr. B.W. Coad (1997) he states that: it is in too poor condition to be of any value, being mostly bones. Coad state, another syntype is listed as NMW 6596 and measures $119.3 \mathrm{~mm}$ standard length. He continued that in 1997 this was the only syntype recognised. The catalogue in Vienna lists only 1 fish, while Heckel's description refers to several fish. NMW 6596 is mostly bones and is dried. The fleshy lip fold of the original description could not be discerned, teeth are missing and the dorsal fin is broken off short [3]. According to. Armantrout N.B (1981) L. barbulus and L. longiceps are very closed and probably the same species. [22]. According to Almaça (1983) L. barbulus is separated from L. mystaceus by having thinner lips, shorter barbels, the last unbranched dorsal ray weaker and shorter, more dense denticles spread over a shorter length of ray, higher anal fin, gill rakers less numerous and the upper dorsal profile is rectilinear and oblique to the back.

On the name of L. barbulus, Coad (1997) stated: I retain it as a species under Heckel's name for this taxon until the systematics of this and related species can be worked out [3].

\section{Results}

Luciobarbus barbulus(Heckel 1846) is valid species and differ from L. mystaceus, $L$ scheich, $L$. kersin, L. pectoralis, L. rajanorum .(see Heckel 1843,1846,1849b)[7, 23,24]

Although there is high degree of overlap in some of meristic and morphometric characters but these taxa differ from each other. L. barbulus is not a subspecies of Luciobarbus mystaceus (Heckel 1846). This species differ from L. mystaceus in having thick and very wide fleshy lip, inferior mouth and slightly shorter head (fig. 1,2,4). In Luciobarbus barbulus the back adjoins with a slight bump directly to the posterior part of the head, so head is more inferior(fig. 1-6) but in Luciobarbus mystaceus with thinner lips pointed head, mouth is subterminal [2]. The body depth after dorsal fin in Luciobarbus mystaceus is thicker and the trunk join to caudal fin with more slope than in Luciobarbus barbulus [28].

In fingerling specimens, the dorsal fin length, head shape and body depth between these two species are more resemble, but in larger fish the proportion of body depth with dorsal in $L$. mystaceus is less, so body is thicker than in L. barbulus. and proportion of head length to body depth in L. barbulus is more than in L. mystacus. (table 1.) In adult fish at same size L. barbulus have more cylindrical body but in L. mystcus body depths is more wider. In small fish head of L. barbulus is smaller or equal in size with head of Luciobarbus mystacus but in adult fish head in L. barbulus will grow more bigger than in L. mystaceus (fig.11).

The obvious features in first view separate these two species are as follow:

Exactly as Heckel(1849) state the lips of Luciobarbus barbulus are thick with wide fleshy lip fold which forms a small median lobe. The dorsal fin, is far less obliquely truncated and when folded back, hardly reaches the beginning of the anal fin." $[7,23,24]$. These fishes have more variable features and sometime abnormality in vertebra or in size of fins. There is probably hybrid between these fishes and other related species, but stated feature are more stable and Luciobarbus barbulus is a distinct species that retain it's shape from fingerling to a giant fish (fig.1-6, 11)

Resent record on present status of these species shows that, for now (2017) it may be caught from nearly all of the places or locality or stations that are mentioned at this paper sometimes with extensive effort per catch, or in some place simply by trapping net or rod and line angling. but because of habituate degradation, pollution and over expedition of water and damming at routes 
for spawning, all of these valuable species are rare and their habitats are under threat, all of these species require précises protection. [25, 26, 27, 28, 29]. As our catch efforts indicate the stock of this species are declining from Azabayjan Ghabi, Mahabad, Kurdestan, Kernanshah, Ilam, Lorestan, Kosestan and Fars province.

The biology and population of these species need more investigation. Information on stock, biology and distribution of these species is inadequate. This fish could be one of best candidate for inland fishery and aquaculture development.

\subsection{Figures, and Tables}

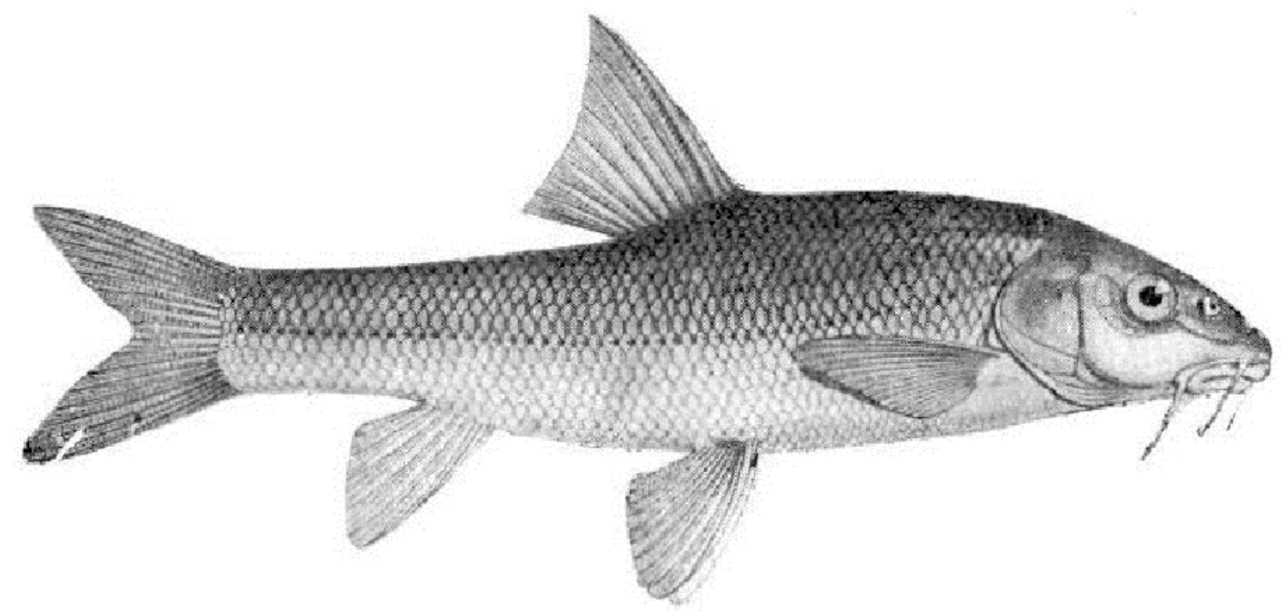

Fig 1. Luciobarbus barbulus Heckel 1846., No 24021, size. 170 mm. Karun basin, After L.S. Berg 1949.

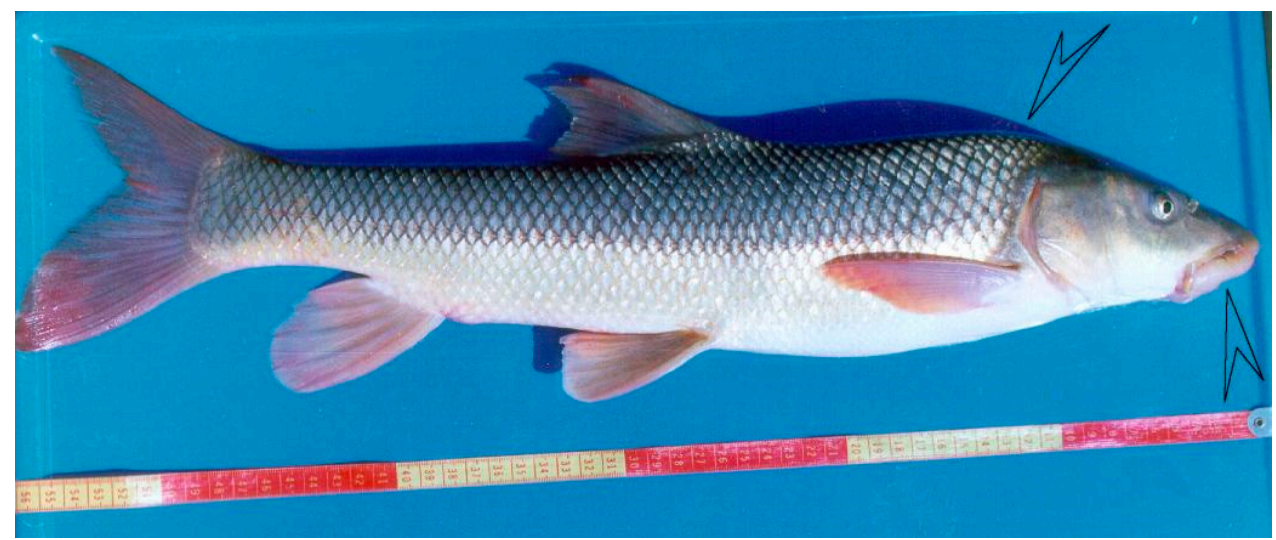

Fig 2 - Luciobarbus barbulus TL 560 mm, Gamasiab River. Image kindly provided by: Mohammad Ghazi, (1996) 


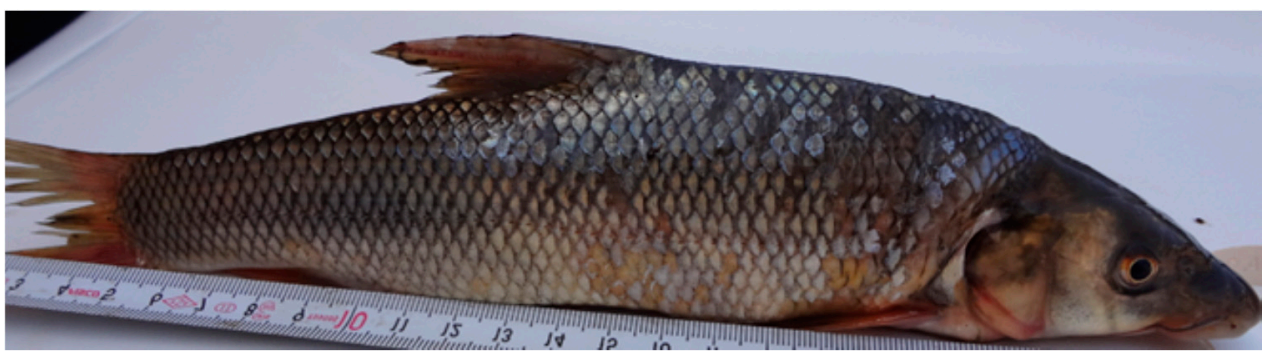

Fig 3- L. barbulus at lesser Zab river in Iran, Peerdanan Station, newly caught specimen by Mohamad Shakiba, 2015, Name of this species at Peranshaher, Mahabad, is PollKey Lowt Kover, = curved head and snout. Image kindly provided by: Mohamad Shakiba, 2015,.
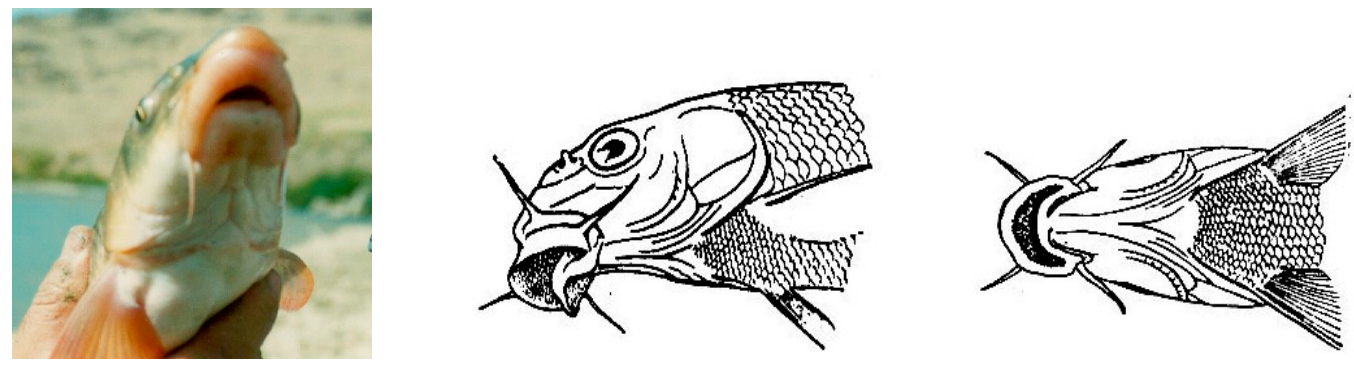

Fig. 4 - Right: Head of L. barbulus Gamasiab River, image kindly provided by: Mohammad Ghazi, (1996) Left: Head of the specimen (No. 24021) lateral and partly ventral views, After Berg 1949.

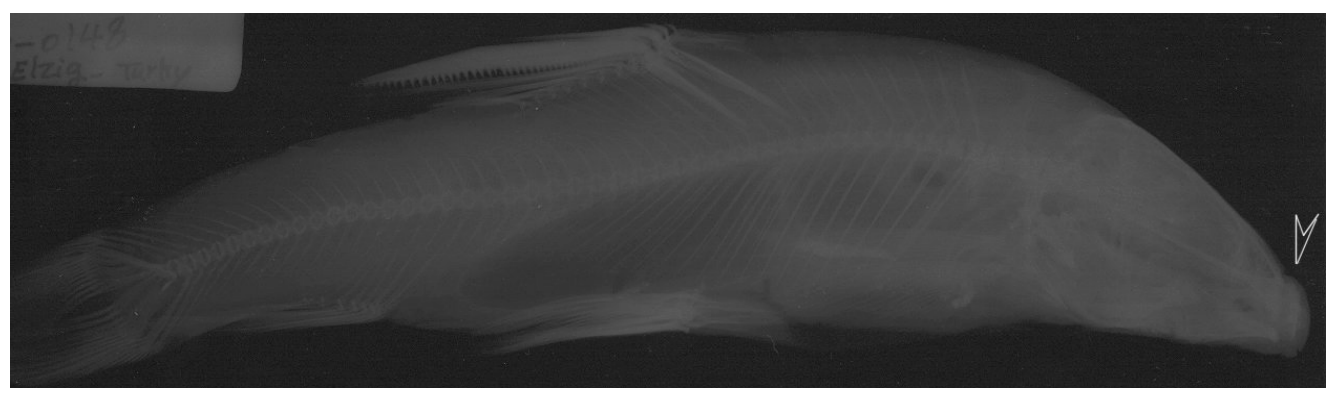

Fig. 5- Xray of Luciobarbus barbulus, 138 mm, SL, Tag No. 40, Shiraz, Firozabad. Below: image provided by: Valiallahi, J. 2000

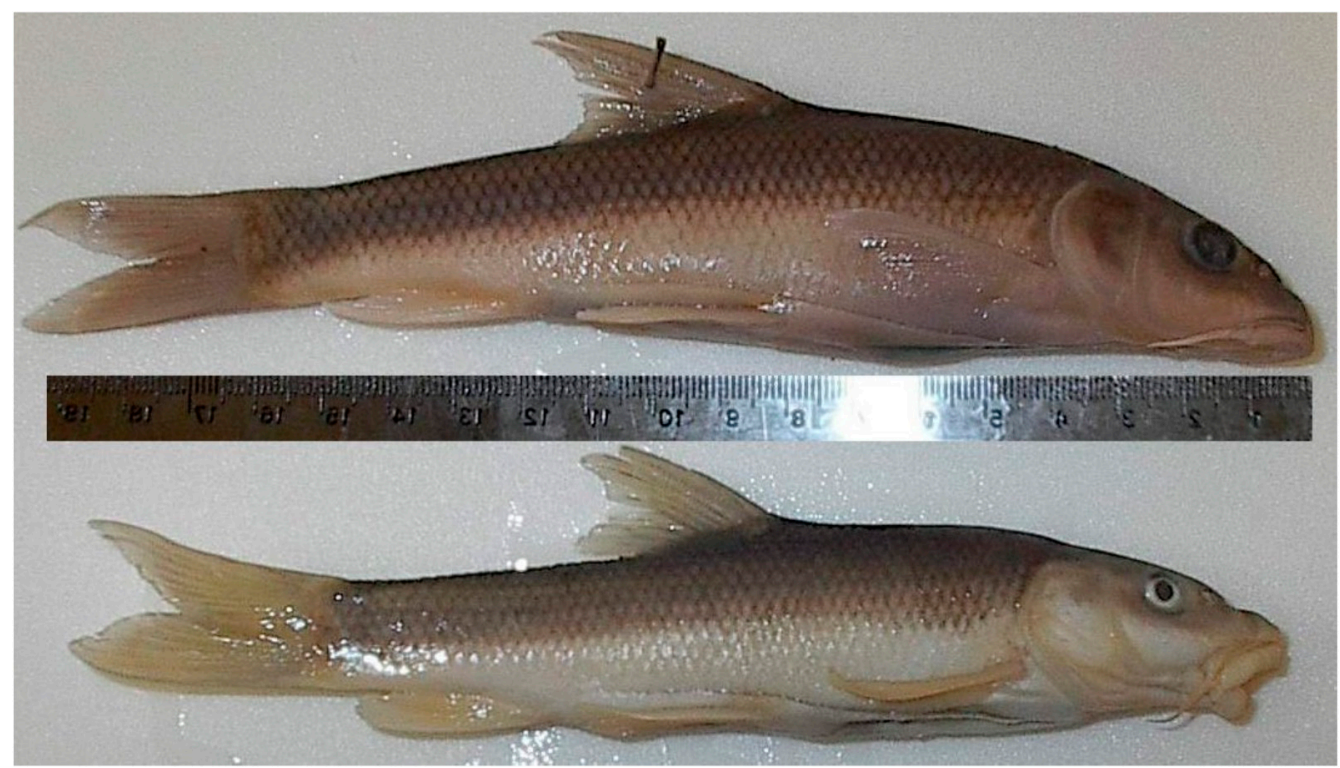


Fig. 6- Above: Luciobarbus barbulus, 138 mm, SL, Tag No. 40, Shiraz, Firozabad image provided by: Below: Luciobarbus persicus Valiallahi, 2000. Holotype, 139 mm SL, Shiraz, Sepidan-Peer district, image kindly provided by: G. Izadi 2001

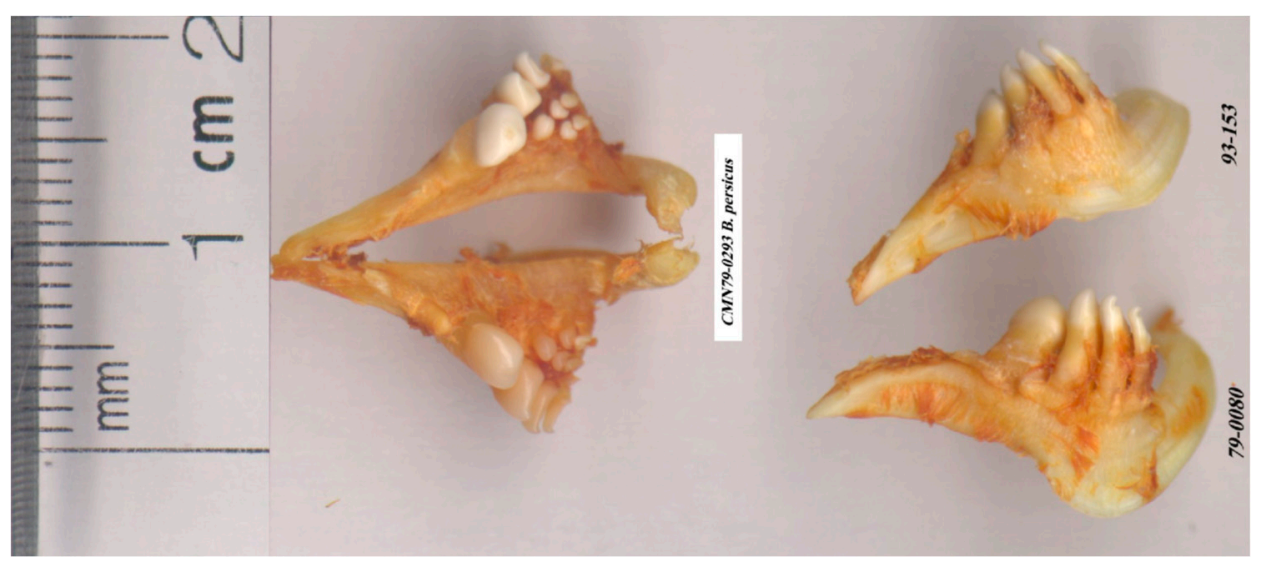

Fig. 7- pharyngeal teeth of L. barbulus and L. persicus, image provided by: Valiallahi, 2000.

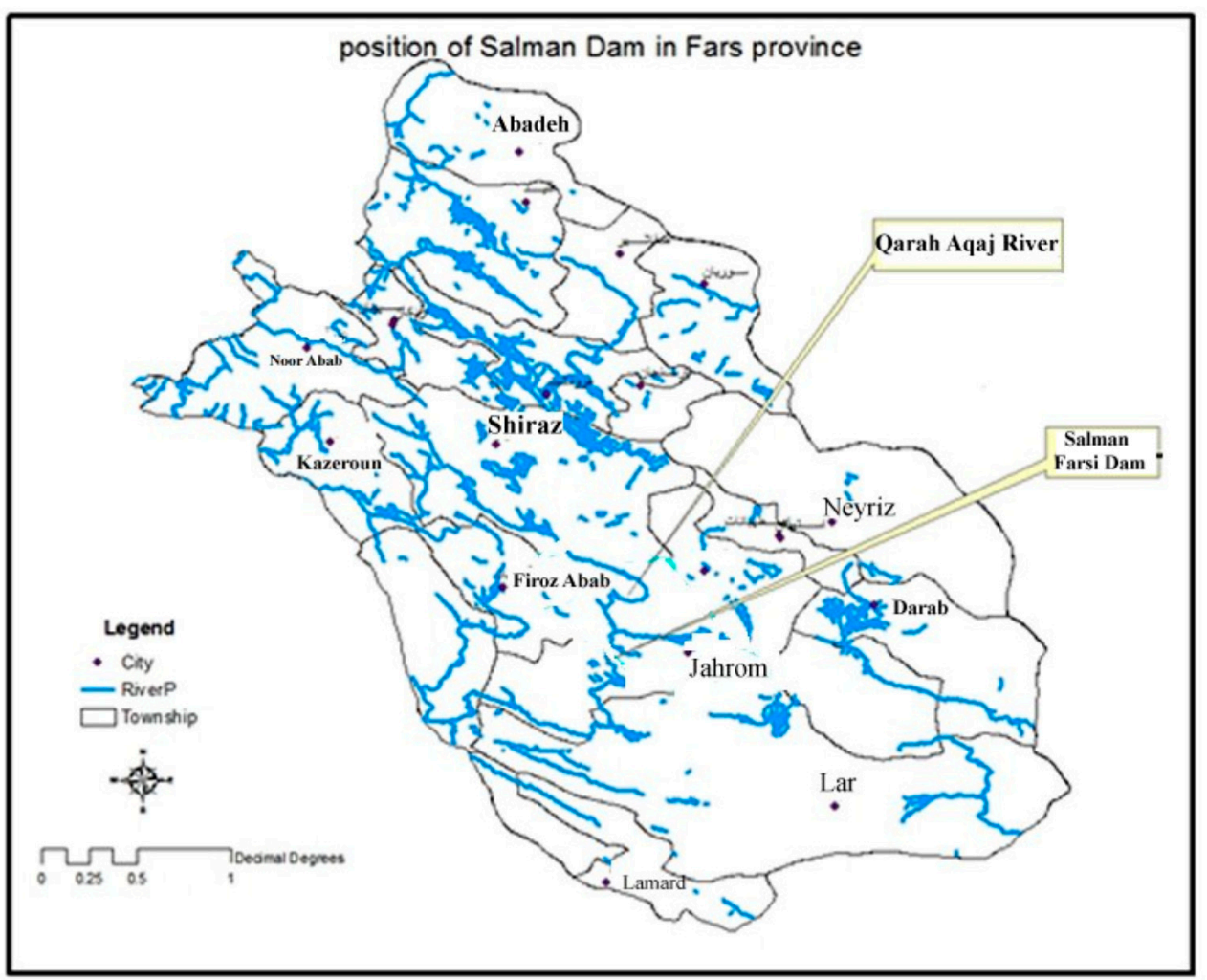

Fig. 8- The layout of Qarah Aqaj River and Salman Farsi dam at Shiraz in Far province, Iran, image kindly provided by: Moradi Ismaeil, 2015. 


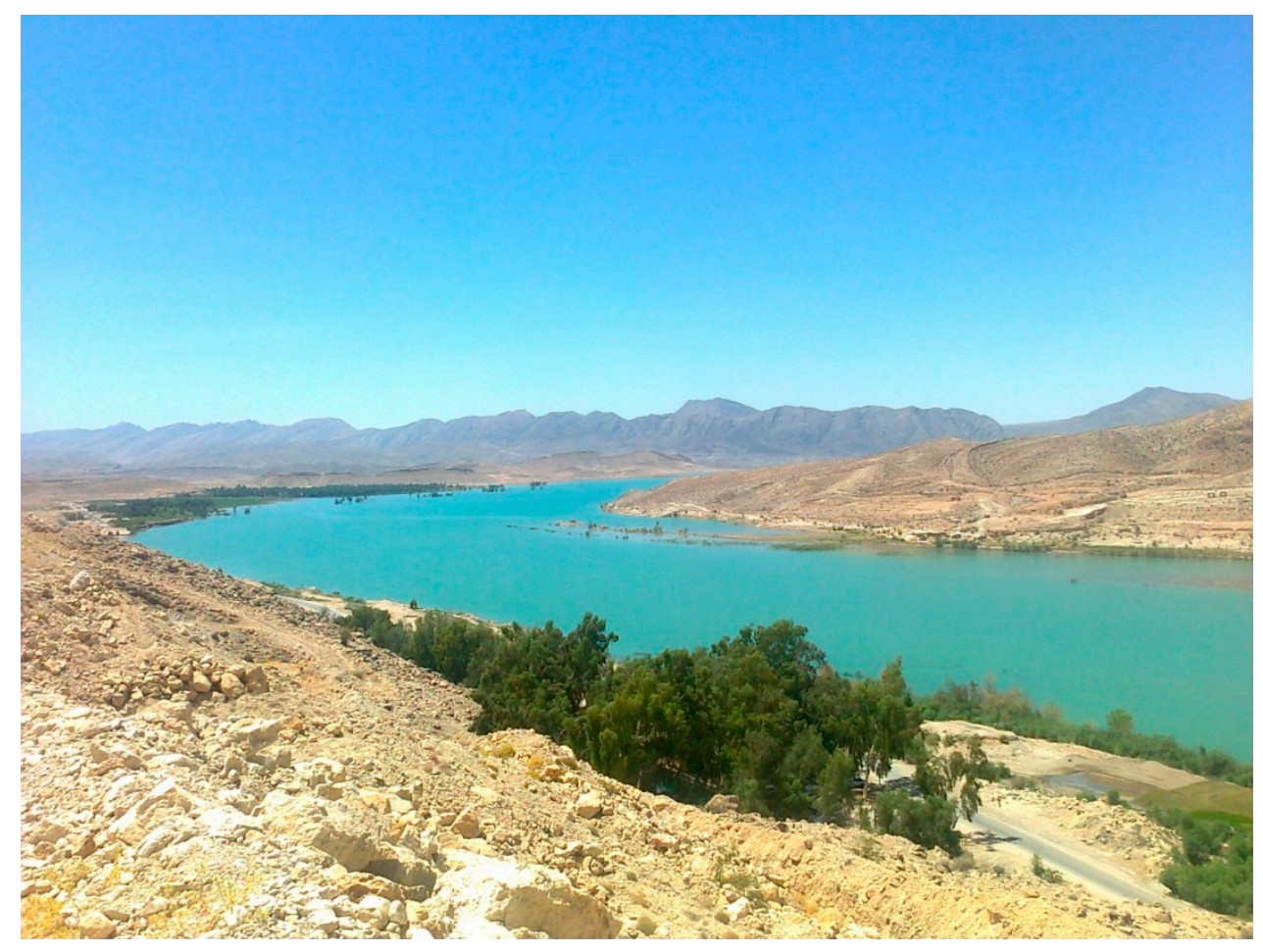

Fig.9 - A typical habitats of L. barbulus, Qarah Aqaj River, in Far province, Iran, image kindly provided by: Moradi Ismaeil, 2015.

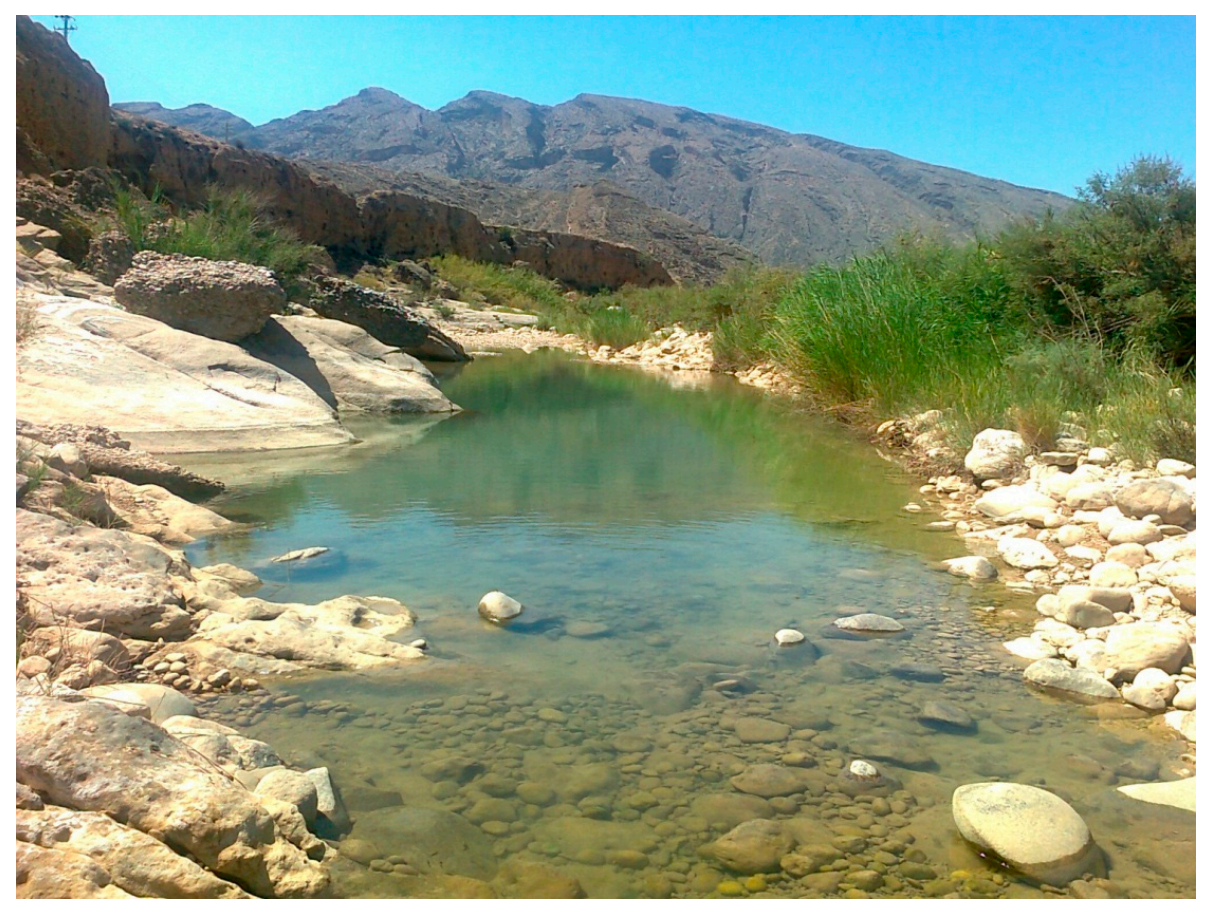

Fig. 10- A typical habitats of L. barbulus, Qarah Aqaj River, $20 \mathrm{~km}$, far from the Salman dam in Fars province, Iran, image kindly provided by: Moradi Ismaeil, 2015. 


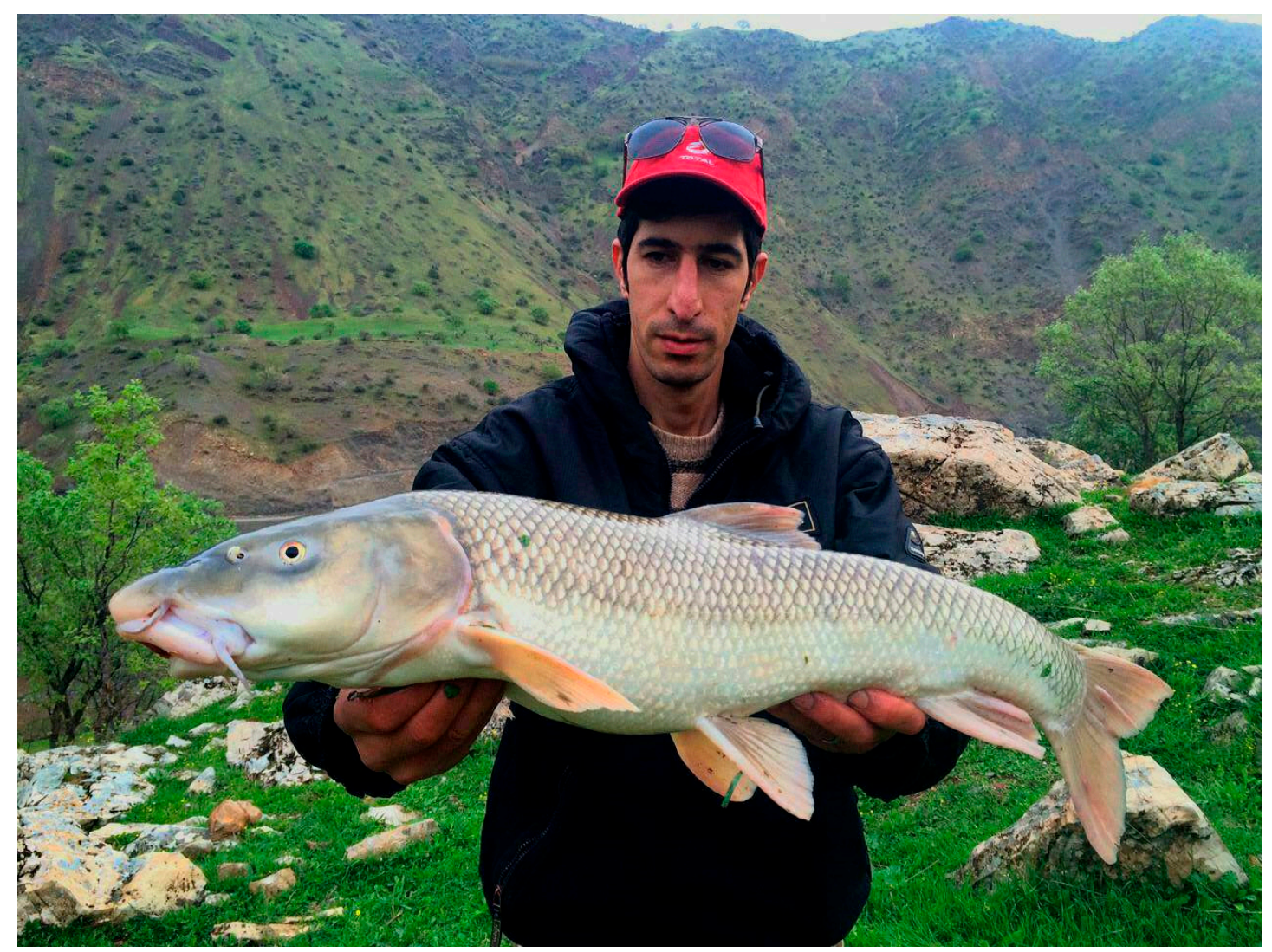

Fig 11. L. barbulus recently caught specimen by Sayed Mohamad Mokhtar Jasemi 2016, from Sirvan river Kurdistan summer 2016, one of the giant fishes of Iran that retain its shape and character's from a fingerling fish to a giant fish, Image kindly provided by: Sayed Mohamad Mokhtar Jasemi, 2016.

Table 1. Range, mean(x)and standard deviation (S.D.) for selected morphometric and meristic characters in Lucioarbus barbulus.

\begin{tabular}{lccccc}
\hline Morphometric and Meristic variables(mm) & range & average & sd & cv & $\mathrm{n}$ \\
\hline Total length: & $108-610$ & 297.8 & 120.7 & 0.41 & 25 \\
Standard length : & $87-505$ & 242.4 & 99.6 & 0.41 & 25 \\
body depth: & $20-114$ & 55 & 20 & 0.36 & 25 \\
Maximum body width: & $13-82$ & 36.1 & 15 & 0.42 & 25 \\
Caudal peduncle length: & $17-75$ & 37.4 & 13.3 & 0.35 & 25 \\
Head length: & $25-130$ & 64 & 24.5 & 0.38 & 25 \\
Diameter of eye: & $13-J a n$ & 9 & 2.6 & 0.29 & 25 \\
Preorbital distance: & Sep-58 & 24.8 & 10.1 & 0.41 & 25 \\
Postorbital distance: & Jan-67 & 30.4 & 12.8 & 0.42 & 25 \\
Dorsal fin height: & $22-100$ & 52.9 & 16.7 & 0.32 & 25 \\
Dorsal fin base length: & Nov-70 & 32.6 & 13.1 & 0.40 & 25 \\
Anal fin height: & $16-91$ & 41 & 15.2 & 0.37 & 25 \\
Length of anterior barbel & $18-\mathrm{Jul}$ & 12 & & 0.00 & 7 \\
Length of posterior barbel & $22-\mathrm{Aug}$ & 13.3 & & 0.00 & 7 \\
Pectoral fin length: & $17-97$ & 44.3 & 16.7 & 0.38 & 25 \\
Ventral fin length: & $16-83$ & 41.3 & 15.1 & 0.37 & 25
\end{tabular}




\begin{tabular}{lccccc} 
Distance pectoral - ventral fin: & $20-145$ & 65.9 & 29.4 & 0.45 & 25 \\
Distance ventral- anal fin: & $20-150$ & 64 & 29.3 & 0.46 & 25 \\
Distance dorsal - pectoral fin: & $18-161$ & 77.1 & 32.2 & 0.42 & 25 \\
Distance dorsal - ventral fin: & $21-113$ & 54 & 20 & 0.37 & 25 \\
Distance dorsal- anal fin: & $29-177$ & 80.8 & 34.4 & 0.43 & 25 \\
Distance dorsal - caudal fin: & $37-251$ & 118.3 & 48.3 & 0.41 & 25 \\
Distance anal - caudal fin: & $20-115$ & 54.4 & 20.7 & 0.38 & 25 \\
Pairs of denticles on last unbrached dorsal ray & $22-36$ & 29 & & 0.00 & 7 \\
Gill racker & $17-24$ & 20 & & 0.00 & 7 \\
HL/Snout & $2.2-3.1$ & 2.6 & 0.2 & 0.08 & 25 \\
HL/Orbit & 5.49 & 8.5 & 8.6 & 1.01 & 25 \\
HL/BD & $1-1.4$ & 1.2 & 0.1 & 0.08 & 25 \\
HL/PecFin & $0.9-1.5$ & 1.2 & 0.2 & 0.17 & 25 \\
TL/HL & $4.1-5.1$ & 4.5 & 0.2 & 0.04 & 25 \\
BD/DFL & $0.9-1.3$ & 1 & 0.1 & 0.10 & 25 \\
SL/HL & $3.5-4.2$ & 3.7 & 0.2 & 0.05 & 25 \\
SL/BD & $3.8-5.3$ & 4.4 & 0.4 & 0.09 & 25 \\
$\quad$ Weight & $\mathbf{1 2 g - 2 1 0 0 g}$ & $\mathbf{3 4 9 . 1 9}$ & & & \\
\hline
\end{tabular}


Table continued: selected morphometric and meristic characters in Lucioarbus barbulus.

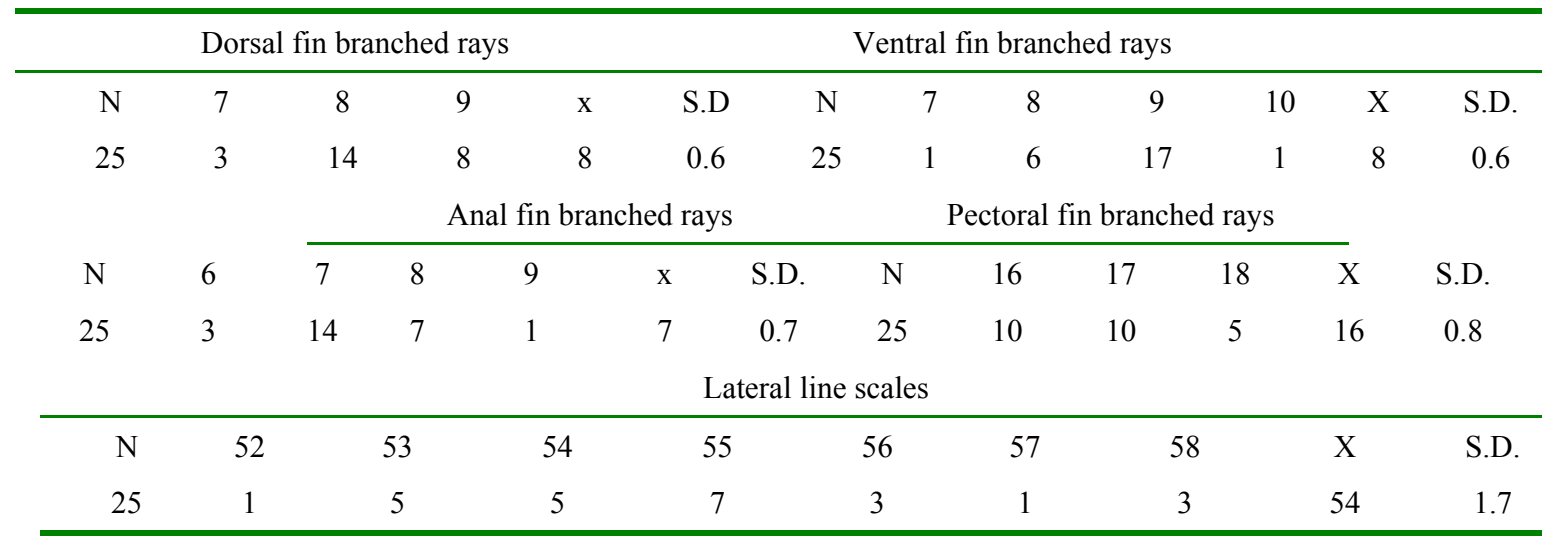

\begin{tabular}{|c|c|c|c|c|c|c|c|c|c|c|c|c|c|c|c|}
\hline \multicolumn{7}{|c|}{$\begin{array}{l}\text { Scale between lateral line and } \\
\text { dorsal fin origin }\end{array}$} & & & & & & \multicolumn{4}{|c|}{$\begin{array}{c}\text { Scale between lateral line and } \\
\text { anal fin origin }\end{array}$} \\
\hline $\mathbf{N}$ & 8 & 9 & 10 & & 11 & & 12 & 13 & $\mathrm{X}$ & S.D & $\mathrm{n}$ & 8 & 9 & $\mathrm{x}$ & S.D. \\
\hline 25 & & 3 & 9 & & 8 & & 3 & 1 & 10 & 1.1 & 25 & 14 & 3 & & 0.6 \\
\hline \multicolumn{8}{|c|}{ Vertebra } & \multicolumn{8}{|c|}{ Proximal pterygiophore } \\
\hline $\mathbf{N}$ & 44 & \multicolumn{2}{|c|}{45} & 46 & $\mathrm{x}$ & & S.D. & \multicolumn{2}{|c|}{$\mathrm{N}$} & 23 & 24 & 25 & 26 & $\mathrm{x}$ & S.D. \\
\hline 6 & 1 & \multicolumn{2}{|l|}{3} & 2 & & 45 & 0.8 & \multicolumn{2}{|l|}{6} & 1 & 1 & 2 & 2 & 24 & 1.2 \\
\hline
\end{tabular}

\section{Discussion}

To clarify, contradiction and suspicious on validity of Luciobarbus barbulus we have to refer on the original writing of Heckel (1846- 1849 b)[7]. When Heckel (1849) received 15 Persian fish species, were collected by Theodor Kotschy around Shiraz, he previously have described the Syrian fish species. Heckle's remarks on L. barbulus and L. mystaceus is clear and obvious, so that eliminate any doubt about differences between Luciobarbus barbulus and Luciobarbus mystaceus. He stated "the water systems around Shiraz yielded the ... 15 species. Considering Luciobarbus barbulus, Heckel (1849) states: "this species is distinguished from all other barbs of Syria by its very wide fleshy lip fold which forms a small median lobe below the symphysis of the lower jaw. This peculiarity reminds us of our Luciobarbus mystaceus, which it resembles remarkably in its entire appearance; however, the head is slightly shorter, the back adjoins with a slight protuberance directly to the posterior part of the head; the dorsal fin, which in Luciobarbus mystaceus, when folded back, reaches past the middle of the anal fin base, is here far less obliquely truncated; its height is only such that, when folded back, it hardly reaches the beginning of the anal fin." Heckel( 1849) stated that this fish inhabits the Kara-Agatsch River; our specimens are 7-8 inches long and were caught near the village of Gere".[7, 23, 24]

Heckel (1849) stated that: "We also have a few, 9 inch long individuals from the Kueik (Queik) near Aleppo which we had considered to be chance deviations of Luciobarbus mystaceus before we encountered the Persian specimens"[23]. When continued description of L. barbulus he stated that "but the most significant deviation [between two species] concerns the pharyngeal teeth of which there are five on the inner row, as in all barbs, but not four as in Luciobarbus barbulus." [24]

Considering pharyngeal teeth Almaça 1990, state: "actually, I only found 4 outer teeth in the specimens belonging to L. mystaceus barbulus, and 4 or 5 in L. mystaceus mystaceus"[9]

Contrary to Almaça 1990 stated remark, our examination shows, that pharyngeal teeth is not distinctive, stable or a good characters for separating these two species. In these two species and other related species, pharyngeal teeth is 2.3.4, rarely 1.3.4 and in some specimens is 2,3,5 or $1,3,5[9][30]$. 
In conclusion according to Heckle,(1849) Luciobarbus barbulus is an species of Persia and is differ from L. mysaceus that were seen both from Shiraz, Iran and in the Kueik (Queik) near Aleppo in Syria.

\subsection{Morphology}

Among all Barbus and Luciobarbus species collected at western Iran and the specimen were examined in CMN, we carried out full analyses and measurement on 25 specimens.

The results are as follow and the measurement are summarised in Table 1:

The inferior mouth is moderate in size, lips are very thick and well developed, sometimes extraordinarily so; lower lip very broad, with a short lobule at symphysis. As stated by Heckel (1849) this species is distinguished from all other barbs of Iran and Syria by its very wide fleshy lip fold which forms a small median lobe below the symphysis of the lower jaw and, the back adjoins with a slight protuberance directly to the posterior part of the head (figland 2). Barbells are relatively thick. Two pairs of barbells, The anterior barbell does not extend past the anterior eye margin level and the posterior one not past the posterior eye margin in all sizes of fish, rostral 1.3; maxillary 1.45 times the diameter of eye.

Head comprised 3.7 times in the standard length and including 2.6(2.2-3.1) times the snout and 8.5 times of the orbit. Standard length including 4.4 (3.8-5.3) times the body depth. Dorsal fin with 4 unbranched 7-9, average of 8 , branched rays, Anal fin with 3 unbranched and range of 6-9 average of 7 branched rays. Upper profile of the dorsal fin rectilinear, slightly concave, and oblique. Last unbranched ray of the dorsal fin and denticles of its rear edge strong. Denticeles long and spread over the $9 / 10$ of the depth of the ray. In older fishes the last unbranched ray contains 36 denticles and in younger 23. Average 29 range 22-36 denticels. when the dorsal fin is pushed back its tip, will not reach or extends scarcely to the origin of anal fin. Origin of the dorsal fin at the same level or slightly forward the origin of the ventral fin.

Pectoral fin branched rays 11-20(average 16), ventral fin branched rays 7-10, average 8. Lateral line scales 52-58, average of 54, S.D. 1.7, mode 55. Above lateral line range 8-13 average 10 below lateral line 7-9 average 7 , (see table 1 ).

Dorsal fin length and proportion of standard length with body depth and head length are important character for Luciobarbus barbulus and other related species, in this species dorsal fin height among 25 specimens with total length of 108-610 average of $298 \mathrm{~cm}$ is between 22-100 mm, average of 52 mostly 56 . (With body Weight from 12 to $2100 \mathrm{~g}$ and average of $349.1 \mathrm{~g}$ ). Gill rakers, 17-24, average 20. Phnryngea1 teeth mostly compressed, otherwise with pointed tip, mostly 4-3-2. The fifth tooth very small and rounded and sometimes absent apparently independent of size.

Considering the size of fishes lives at the Zagross mountain basin rivers, after L. esocinus, L. barbulus is the second large Barbus species, that will attain size of some $1.5 \mathrm{~m}$, with a weight of about $90 \mathrm{~kg}$ or more.

\section{2 Colour}

The back and upper flank are dark greyish. The lower flank and the belly whitish. Upper flank scales are outlined with pigment, and the anterior edge of the dorsal fin and the caudal fin margin are yellow bright red in fresh fish specimens. The colour in different locality is slightly different and mostly is uniform. The back is dark greyish and the lower part of body whitish. The overall colour is silvery and the anal and caudal fin lobe sometimes are bright red. The dorsal fin is grey and the pectoral and pelvic fins yellowish to bright red. The peritoneum is black.

\subsection{Similarity and Local and Common names:}

Overall morphology points to a close affinity between $L$. mystaceus, $L$ scheich, , L. rajanorum, $L$. belayewi. Although there are several arabic and local names for these species but apparently local fisherman do not distinguish differences between all individual of these group, in Kermanshah province local fisherman called these group by name of Dolenj.

lab pahn (= broad lip), برزم (berzem or barzam); berzem lab pahn in Khuzestan and Iraq to distinguish it from Luciobarbus pectoralis; boz mahi (=goat fish) or سس ماهي (= SAS mahi in the Dalaki and Shapur River basins)[3] 
Arabic name is $\boldsymbol{A b u - B a r a t t u m . ~ ( M a h d i ~ 1 9 6 2 ) . ~ A b u - B a r a t e m ~ , ~ N a b b a s h [ 1 0 ] . ~ A t ~ L a s e r ~ Z A B ~ i n ~ I r a n , ~}$ Peerdanan Station, name of this species at Peranshaher, Mahabad, is PollKey Lowt KoVer, يولهكه لوتكوور = curved head and snout.) Mahi Lab Gholveei(= broad lip)[25].

\section{Materials and Methods}

Luciobarbus barbulus:

All specimen with CMN signs are museum specimens that are keep at Canadian Museum of Nature, they have catalog number or Tag in corner of fish mouth or any number such as 131(231). J.V.C is abbreviation for Jalal Valiallahi Collection, refer to specimen's collected By J. Valiallahi et.al. from Iran during 1985 to 2015.

Among these 34 specimens preserved in CMN only 7 specimens recognized as Luciobarbus barbulus, , 4 specimens are aberrant specimens, which have disorder in body shape, variable number of vertebra or exhibited characters intermediate between two more related species.

Calculating for morphometric and meristic characters for Luciobarbus barbulus was carried out on specimens in CMN and 18 specimens among J.V.C.

(1) Catalog number CMN 93-0153, 280 mm TL, 230, SL $q$ Khuzestan-Zohreh R. collector; I. Sharifpour, 1991.

$(\mathbf{2 , 3 , 4 )}$ CMN, 131(231).[small ,108mmTL,87mmSL; medium,112mm TL,90 mm SL; big $160 \mathrm{~mm}$ TL, 140 mm SL, q 4.3.2 PT; Kordestan - Qeshlaq R. south of Sanandaj, 35/16 N 47/01 E ;Coad 1976.

(5) CMN Tag- M 2188; 223 mm TL 178 mm SL, , , Kermanshah, Gamasiab R. Qharah Su or GHARAH SO 3410 N 4721 E, Jalal Vaiallahi ,28 Apr. 1997-8.

(6)CMN 88-0148; 236mm TL,194mm SL. Turkey, Elazig, Keban dam,on Euphrates, 3848 N,38 45 E, Sarieyyüpoğlu 1987;

(7)CMN, Shiraz, Noor Abad-Garab 2001; 195mm, TL; 159mm SL, đ̊

(8) J.V.C GM-76, 301 mm TL, 237 mm SL, Gamasiab River 1997.

(9)J.V.C J-7, 295mmTL,250mm SL, Gamasiab-Garous1999, $38 \quad 18$ N 4602 E.

(10) J.V.C J-6, 304mm TL, 244 mm SL, Sirvan R.-1999

(11) J.V.C 610 Alvand , 610 mm TL, 500 mm SL, Alvand R. 199934 /18 N 45 /11E

(12) J.V.C 50 Sirvan, 610 mm TL,505 mm SL, Sirvan-Daryan2000

(13) J.V.C 29/6, 283 mm TL, 225 mm SL, Garrous, Gamasiab River 1999- 38 /18 N 46 / 02

(14) J.V.C GM-80, 375 mm TL, 295 SL, Gamasiab -1999

(15) J.V.C 16687, 373 TL, 297 SL, Gamasiab R. Lived for 2 month in aquarium 1998.

(16) J.V.C 273Garrous , 273 mm TL, 237 SL , Gamasiab-Garrous 1999- 38 /18 N 46 / 02

(17) J.V.C CH-3, 166 mm TL, 145 mm SL, Gamasiab River-2000

(18) J.V.C 222, 225 mm TL, 183 mm SL, Sirvan-Shakhan-1999

(19)J.V.C 1669; 237mm TL, 196 mm SL, Zimkan R.-1999

(20)J.V.C J-3, 290 mm TL, 239 mm SL, Sarab Nilofar

(21)J.V.C GM-77, 296 mm TL,247 mm SL, Gamasiab-1999;

(22)J.V.CGarruos,325mm TL,270 mm SL. Lived for 2 month in aquarium;

(23)J.V.C Rika 2000, 327mm TL,271 mm SL, Rika, Ravansar, 3443 N 4640 E 2000

(24)J.V.C, GM- 79, 340mm TL, 286 mm SL, Gamasiab-1999.

(25)J.V.C GH-34, 370 mm TL,305 SL, Gamasiab R. 2000.

Aberrant and anomalous specimens:

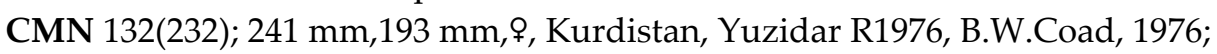

CMN 133(233), 190 mm, 150 mm; Sar-pol-e-Zuohab, 34-36- N; 45-56-E;

CMN 139(239) medium one, 160mm TL, 137 mm SL, see no. (17) below.

CMN Tag 2187, Kermanshah, Gharaso R. J. Valiallahi, 1997

Comparative material

For comparing measurement carried out on 26 specimens that were distinguished as $L$. mystacius 24 specimen imperfectly haven named as L. b and 2 specimen as Luciobarbus pectoralis, these specimens are:

CMN 91-0154 big one, 340 mm TL. 280 mm SL; Hour-Al-Azim; Sep. 1991. 
CMN, 91-0154, small one, 330 mm TL, 265 mm SL. Same locality and collector as big one.

Also comparative material were 4 specimens of Barbus longiceps Valenciennes,(1842),

with catalog number of 80-0835, from Israel, Lake of Galilee, Jul 1981. With $187-286 \mathrm{~mm}$ TL length, 154-229 mm SL.

\section{Conclusions}

Resent record on present status of these species shows that, because of habituate degradation, pollution and over expedition of water, all of these species are rare and their habitats are under threat, all of these species require protection. [25, 26, 27, 28, 29]

The biology and population numbers of these species need more investigation. Information on stock, biology, distribution of these species is scarce and just a few information, because of misidentifying species, or confusing them with other related species may not be scientifically valid. We hope the shape and record documented in this paper would be useful for identifying this defined species from other related species. This fish could be one of best candidate for Inland water Aquaculture Development.

6. Acknowledgments: Part of this paper is from the corresponding author $\mathrm{PhD}$. Theses carried out at Tarbiat Modares University and Canadian Museum of Nature. We are grateful to the staff of this great museum and Dear Amin Kayvan for his help and encouragement, and hope. (is no more among us, God blessed his soul). The study on newly caught species was funded by Iran National Science Foundation (INSF), project No. 91001954. The authors thank the colleagues at this institute. Then more grateful to all of our Iranian friends in Ministry of Agriculture the department of Fishery and Aquaculture of Kermanshah; Mohamad Ghazi, Shahmahmodi S.; Bidel R.; Haidary B. We would like thank Members of the Board of Directors of Scientific Aassociation of Environmental Education and Sustainable development EESD www.eesd.ir for ethical approval of performing the project and monitoring its implementation process in accordance to the laws and regulations of IUCN in the treatment to animals. This project approved in Shahid Rajaee Teacher Training University, so it is our duty thanks all of the staff of these institution.

7. Author Contributions: For this research articles Valiallahi J. wrote the paper, comprehended and designed the experiments; performed the experiments; analyzed the data; Dr. Coad Brian W. contributed reagents/materials/analysis tools and supervised the $\mathrm{PhD}$. Theses, ethnically edited and revised draft manuscript advise and has given critical suggestions"

8. Conflicts of Interest: "The authors declare no conflict of interest." Authors identify and declare that: are ready for give explanation to any personal circumstances or interest that may be perceived as inappropriately influencing the representation or interpretation of reported research results; any role of the funding sponsors in the design of the study; in the collection, analyses or interpretation of data; in the writing of the manuscript, or in the decision to publish the results. "The founding sponsors had no role in the design of the study; in the collection, analyses, or interpretation of data; in the writing of the manuscript, and in the decision to publish the results".

\section{References}

1. Valiallahi, J. 2006. Identification of Barbus plebjus (Bonaparte, 1832) a valid species of cyprinid fish from Iran. Iranian Journal of Biology, 19(1):109-116. In Farsi.

2. Heckel, J. J. 1846-1849a. Naturhistorischer Anhang. In: Russegger, J. Reisen in Europa, Asien und Afrika, mit besonderer R $\ddot{Y} c k s i c h t$ auf die naturwissenschaftlichen VerhŠltnisse der betreffenden LŠnder, unternommen in den Jahren 1835 bis 1841 von Joseph Russegger. Schweitzerbart'sche Verlagsbuchhandlung, Stuttgart, 2(3):207-254, Taf. XIV-XXI.

3. Coad, B. W. 2017, Freshwater Fishes of Iran, Species Accounts, Cyprinidae Garra to Vimba, Revised: 03 June 2017. www.briancoad.com

4. Almaça, C. 1986. On some BARBUS species from Western Asia (Cyprinidae, Pisces). Annalen des Naturhistorischen Museums in Wien, B, 87:5-30.

5. Coad Brian W., 2009, " Threatened fishes of the world: Luciobarbus subquincunciatus (Günther, 1868)

(Cyprinidae) " Springer Science + Business Media B.V. 2009 
6. Casal-Lopez, M., Perea, S., Yahyaoui, A. \& Doadrio, I. (2015): Taxonomic review of the genus Luciobarbus Heckel, 1843 (Actinopterygii, Cyprinidae) from Northwestern Morocco with the description of three new species. Graellsia, 71 (2): e027.

7. Heckel, J. J. 1846-1849b. Anhang. Die Fische Persiens gesammelt von Theodor Kotschy. In: Russegger, J. Reisen in Europa, Asien und Afrika, mit besonderer R ̈̈cksicht auf die naturwissenschaftlichen VerhŠltnisse der betreffenden LŠnder, unternommen in den Jahren 1835 bis 1841 von Joseph Russegger. Schweitzerbart'sche Verlagsbuchhandlung, Stuttgart, 2(3):255-272, Taf. XXII.

8. Hubbs, C.L. \& Lagler, K.F. 1964 . Fishes of the Great Lakes Region. Ambassador Books Ltd., Toronto. Xv + 213 pp., 44 pls.

9. Almaça, C. 1991. Evolutionary, biogeographical, and taxonomical remarks on Mesopotamian species of Barbus s.s. Arquivos do Museu Bocage, nova série, 2(4):63-78.

10. Khalaf, K. T. 1961. The marine and freshwater fishes of Iraq. Ar-Rabitta Press, Baghdad. 164 pp.

11. Berg, L. S., 1948-1949: Freshwater fishes of the USSR and adjacent countries. Israel Program for Scientific Translations, Jerusalem (1962-1965), 3 Volumes.

12. Mahdi, N. 1962. Fishes of Iraq. Ministry of Education, Baghdad. 82 pp. Mahdi, N. and Georg, P. V. 1969. A systematic list of the vertebrates of Iraq. Iraq Natural History Museum Publication, Baghdad, 26:1-104.

13. Saadati, M. A. G. 1977. Taxonomy and distribution of the freshwater fishes of Iran. M.S. Thesis, Colorado State University, Fort Collins. xiii +212 pp.

14. Valiallahi J. (2000),Ph.D theses: Molecular \& Morphologic Taxonomy of Barbus spp. in western Iran; Natural Resources faculty, University of Tarbiat Modares, Tehran Iran.

15. Howes, G. J. 1987. The phylogenetic position of the Yugoslavian cyprinid fish genus Aulopyge Heckel, 1841, with an appraisal of the genus Barbus Cuvier \& Cloquet, 1816 and the subfamily Cyprininae. Bulletin of the British Museum (Natural History), Zoology, 52(5):165-196.

16. Almaça, C. 1983. Remarks on some Heckel's species of Barbus from western Asia. Arquivos do Museu Bocage, B, II(12):95-102.

17. Krupp, F. 1985a. Rehabilitation of Barbus lorteti Sauvage, 1882, and comments on the validity of the generic names Bertinius Fang, 1943, and Bertinichthys Whitley, 1953 (Pisces: Cyprinidae). Hydrobiologia, 120:6368.

18. Krupp, F. 1985b. Barbus chantrei (SAUVAGE 1882), a valid species of cyrinid fish from the northern Levant (Pisces: Osteichthyes: Cyprinidae). Senckenbergiana biologica, 66(1/3):17-25.

19. Krupp, F. 1985c. Systematik und Zoogeographie der Süßwasserfische des levantinischen Grabenbruchsystems und der Ostküste des Mittelmeeres. Dissertation zur Erlangung des Grades "Doktor der Naturwissenschaften" am Fachbereich Biologie der Johannes Gutenberg - Universität in Mainz. 215 pp., Anhang: Abbildungen, Karten, Tabellen, 169 pp.

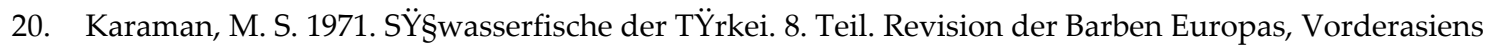
und Nordafrikas. Mitteilungen aus dem hamburgischen Zoologischen Museum und Institut, 67:175-254.

21. Karaman, M. S. 1972. S吕wasserfische der TŸrkei. 9. Revision einiger kleinw $\ddot{Y} c h s i g e r$ Cyprinidengattungen Phoxinellus, Leucaspius, Acanthobrama usw. aus SŸdeuropa, Kleinasiens, VorderAsien und Nordafrika. Mitteilungen aus dem hamburgischen Zoologischen Museum und Institut, 69:115155.

22. Armantrout, N.B.(1980) The Freshwater Fishes of Iran. Ph. D. Thesis, Oregon State University, $x x+472$

23. Heckel, J. J. 1846-1849c. Nachtrag zur Charakteristik und Classifikation der Cyprineen-Gattungen. In:

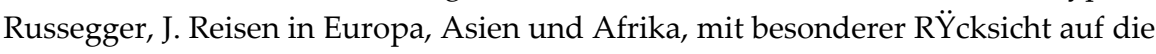
naturwissenschaftlichen VerhŠltnisse der betreffenden LŠnder, unternommen in den Jahren 1835 bis 1841 von Joseph Russegger. Schweitzerbart'sche Verlagsbuchhandlung, Stuttgart, 2(3):273-290.

24. Heckel, J. J. 1846-1849d. Index. Addenda et Corrigenda. In: Russegger, J. Reisen in Europa, Asien und Afrika, mit besonderer RŸcksicht auf die naturwissenschaftlichen VerhŠltnisse der betreffenden LŠnder, unternommen in den Jahren 1835 bis 1841 von Joseph Russegger. Schweitzerbart'sche Verlagsbuchhandlung, Stuttgart, 2(3):347-360.

25. Valiallah J. 2015, View on present status of large Barbus species of Iran, National project No. 91001954. Iran National Science Foundation (INSF)(in Farsi).

26. Valiallahi J. Moradi Ismaeil, 2015. The fishes of Qarah Aquaj River territory at Fars province. Un pub.

27. Valiallahi J. 2000. Uniquely significant fresh water fishes of Iran are exposed to environmental stress. Journal of Environmental Studies, 26(25):29-38. In Farsi. 
28. Valiallahi, J. 2004. Habitats, distribution and notes on Barbus mystaceus and Barbus barbulus, the two Barbus species of Iran. Journal of Environmental Studies, Tehran, 29:27-34, 4. In Farsi.

29. Valiallahi J. ' Shakiba M. 2015, Msc. Theses of Shakiba, Effects of pollution and development on biodiversity of fishes in Laser Zab, Peranshaher, West Azarbayjan, Iran.

30. Valiallahi J.; Shahmahmodi S.; Bidel R.; Haidary B; Ghazi M; Jaliliyan M.(1998) " The Fishes of Three major River of Kermanshah Province.(Gamasiab, Gharaso, Razavar),Final Report of Research Plan; Kermanshah Fishery Research(J.V.C) of Natural Resources and Animal Husbandary 